\title{
TAX COMPETITION IN A FISCAL UNION WITH DECENTRALIZED LEADERSHIP
}

\author{
MARKO KÖTHENBÜRGER
}

CESIFo Working PAPER No. 943

CATEGORY 1: PUBLIC FINANCE

MAY 2003

\footnotetext{
An electronic version of the paper may be downloaded

- from the SSRN website: www.SSRN.com

- from the CESifo website: www.CESifo.de
} 


\title{
TAX COMPETITION IN A FISCAL UNION WITH DECENTRALIZED LEADERSHIP
}

\begin{abstract}
This paper examines capital tax competition in the presence of an interstate transfer policy without federal commitment. Lack of commitment implies that tax policy is chosen prior to federal transfers. The paper's main result is that ex-post federal policy internalizes horizontal fiscal externalities, insulating tax policy from capital mobility. Federal policy, however, introduces a new source of inefficiency unrelated to tax competition. Specifically, ex-post transfer payments prove to be equivalent to an interstate revenue-sharing system which may render federal intervention in the presence of fiscal externalities welfare-deteriorating relative to tax competition.
\end{abstract}

JEL Code: H7, H3, H1.

Keywords: federalism, capital tax competition, commitment, soft budget constraints.

\author{
Marko Köthenbürger \\ CESifo (University of Munich \& Ifo Institute) \\ Poschingerstrasse 5 \\ 81679 Munich \\ Germany \\ mkoethen@ces.vwl.uni-muenchen.de
}

I am grateful for useful comments from Clemens Fuest, Christian Keuschnigg, Hans-Werner Sinn and seminar participants at CES, at the University of St. Gallen, and at CEBR (Copenhagen). I also benefited from comments received at the PET conference in Paris, July 2002, and at the annual conference of the German Economic Association in Innsbruck, September 2002. 


\section{Introduction}

Tax competition is a prevalent feature in the globalized economy, being of concern to policy-makers and academics alike. Though following Zodrow and Mieszkowski (1986), a lot of attention is confined to tax competition among politically independent states, in many cases however competing states are members of the same fiscal union. For example in federal economies, such as Germany, U.S.A. and Canada, taxing powers are partially assigned to lower level governments, which allows them to compete for mobile capital (see Messere, 1998). Tax competition in a fiscal union differs from inter-union competition in at least two respects. Lacking political and legal barriers, intra-union capital mobility tends to be higher, magnifying concerns of tax competition. More importantly, member states are linked by a common federal tax-transfer policy, which can be expected to significantly alter local incentives to engage in tax competition. However, the hierarchical structure of the public sector is generally neglected in models of tax competition, as pointed out in Oates (1994), though it may yield efficiency effects different to those predicted by the standard Zodrow-Mieszkowski-type model and used in policy debate.

This paper analyzes tax competition in a fiscal union with decentralized leadership. In particular, the paper adopts a two-layer fiscal union in which the federal level redistributes public funds across states. Member states engage in tax competition and receive transfers from the federal budget. Decentralized leadership implies federal redistributive policy to be chosen after states have decided upon tax policy. States thus anticipate the federal level responses to local tax reforms. This strategic consideration, referred to as the soft-budget constraint syndrome, is found to have significance in real-world federal politics. Lower level governments are frequently suspected of choosing public debt levels at a too high level triggered by expectations of a federal bailout granted if they are rendered insolvent. Some indications of a soft-budget constraint are provided e.g. for the 
U.S. in Poterba (1995) and for Germany in Rodden (2003). Drawing on case studies of major federal economies, political competition or constitutional provisions are identified as two potential candidates for why the federal government reacts ex-post to policy changes in member states; see Rodden et al. (2003). If fiscally-troubled states contain voters, which are politically decisive in federal elections, federal politicians will favor bailing out these states. Alternatively, a constitutionally-anchored "grandfathering" role for the federal government forces the upper level to respond to unsound local fiscal policies by providing funds. ${ }^{1}$

Apart from constitutional and political factors, the sequence of moves may also inherently originate from the type of fiscal policies both layers of government pursue. Large scale tax reforms typically occur in larger time intervals. In contrast, transfers are set over a shorter time-horizon, implying that local tax policy is implemented prior to transfers.

The present paper does not provide a rationale for a soft-budget constraint. Instead, it focuses on its efficiency implications when confronted with fiscal competition. The paper's main finding is that soft budget constraints internalize fiscal externalities. Anticipating that ex-post federal transfers tend to equate public revenues in each state, the impact of tax rate changes on other states' budget is internalized. However, federal transfers spread the social effects of marginal tax changes equally across all member states. Specifically, ex-post federal intervention allocates only a fraction of the social effect to the state raising the tax rate which, in turn, dilutes incentives to tax capital. In other words, decentralized commitment insulates states from harmful tax competition. Local tax policy becomes independent of capital mobility. On the other hand, decentralized commitment effectively turns lump-sum redistribution into a revenue-sharing system, rendering tax policy inefficient for reasons other than tax competition.

\footnotetext{
${ }^{1}$ Such a "grandfathering" role is e.g. prescribed by the German constitution. Enforcing this principle, the German supreme court has repeatedly instructed the federal government to provide bailouts to needy states; see Rodden (2003).
} 
Welfare analysis reveals that federal policy may reduce welfare relative to tax competition without federal intervention. Surprisingly, tax competition may be welfare-superior in the presence of high capital mobility.

The paper contributes to the literature on tax-transfer policy in federal systems. In most parts of the literature, federal policy improves welfare. By implementing a Pigouvian-type transfer scheme (Dahlby, 1996) or even by using lump-sum transfers (Boadway and Keen, 1996, and Boadway et al., 1998), federal policy offsets inefficiencies in lower-level decision-making. A unifying assumption underlying this body of literature is that the federal government can commit itself towards lower-level governments (top-down commitment). The seminal paper by Boadway and Flatters (1982) equally stands in this tradition. Federal transfers are shown to prevent fiscally-induced migration by levelling out net public benefits accruing to households in different regions. In accomplishing this, the federal layer has to be able to commit to the equalization system.

The role of decentralized commitment in fiscal federalism has only been addressed recently. Silva and Caplan (1997) and Caplan et al. (2000) analyze federal policy in the presence of transboundary externalities generated either by pollution or public consumption spill-overs. In these models, decentralized commitment proves beneficial since it allows externalities to be internalized. The results conform to the traditional public finance view which favors federal intervention in the presence of local inefficiencies. In contrast, ex-post federal policy may also impose disincentives on lower-level governments (Wildasin, 1997). Anticipating a federal bailout, state governments are inclined to qualify for additional funds by strategically under-providing local public goods. ${ }^{2}$ All these papers however abstract from issues of tax competition. Closest to this paper is Qian and

\footnotetext{
${ }^{2}$ Similarly, lacking federal commitment, federally-mandated equalization schemes tend to reinforce rather than to offset fiscally-induced migration incentives which undermines welfare (Mitsui and Sato, 2001). Different to this paper, Mitsui and Sato allow private agents to make their decisions prior to policy formation. The assumption on intergovernmental commitment, however, follows the traditional top-down commitment approach.
} 
Roland (1998). They investigate the merits of decentralized leadership and fiscal competition in reducing bail-outs of private firms. Though similarly pointing to an efficiency-enhancing role of decentralized commitment, they do not provide a detailed analysis of the intergovernmental incentive structure in tax competition. The internalization effect, inherent in ex-post transfer setting, makes no appearance in their paper.

Finally, by proposing an internalization mechanism for horizontal fiscal externalities, the paper complements recent literature, demonstrating that household mobility (Myers, 1990) and local provision of international public goods (Bjorvatn and Schjelderup, 2002) have the potential to internalize fiscal externalities. ${ }^{3}$ Common to these contributions, the present paper therefore suggests demand for tax coordination to be less pronounced than indicated by the standard tax competition model.

The paper proceeds as follows: Section 2 presents the set-up of the basic model. Section 3 analyzes tax policy if neither level of government can commit. The effects of decentralized commitment are presented in Section 4 followed by a welfare analysis in Section 5. Section 6 is devoted to extensions of the basic model. A summary and some concluding remarks are offered in Section 7. All proofs are relegated to the Appendix.

\section{The Model}

Consider an economy with $n \geq 2$ identical states each consisting of a representative household and a representative firm. The former derives utility from private and public consumption denoted by $c$ and $g$, respectively. Preferences are given

\footnotetext{
${ }^{3}$ Transfers are also present in Myers. Regions may voluntarily transfer resources interregionally in order to "buy" the preferred population size therein. He does not, however, employ an institutionalized transfer system, nor does he model incentives in hierarchical governments (by assuming a one-layer government). The internalization mechanism based on decentralized commitment, proposed in this paper, is thus different to the one suggested by Myers. In fact, household mobility and ex-post transfers complement each other as shown in Section 6.
} 
by

$$
u=c+b(g)
$$

where $b(\cdot)$ is strictly increasing and concave. Subsequently, ${ }^{4}$

$$
\lim _{g \rightarrow \infty} b^{\prime}(g)=0, \quad \text { and } \quad \lim _{g \rightarrow 0} b^{\prime}(g)=\infty .
$$

The budget constraint reads

$$
c=I+r \tilde{k}
$$

where $I$ is income generated by a fixed factor (say land) owned by the representative household, $r$ is the interest rate, and $\tilde{k}$ denotes the capital endowment of each household normalized at unity.

Each state produces a single good using the neoclassical production technology $f(k)$, which exhibits constant returns to scale. ${ }^{5}$ Output can be used on a one-to-one basis for private and public consumption. The representative firm in each state maximizes profits $\pi=f(k)-(r+t) k$ with $t$ as the source-based capital tax rate. Profit maximizing input choices follow from the first-order condition $f^{\prime}(k)=r+t$, which defines capital demand as a function of the rental price of capital, $k=k(r+t)$. The assumption of constant returns to scale implies $I=f(k)-f^{\prime}(k) k$.

$$
f^{\prime}(k)=r+t \text { and the capital market clearing condition } \sum_{i=1}^{n} k^{i}=n \tilde{k} \text { charac- }
$$
terize a capital market equilibrium. Differentiation yields

$$
\frac{\partial k^{i}}{\partial t^{i}}=\frac{n-1}{n} \frac{1}{f^{\prime \prime}(k)}<0, \quad \frac{\partial k^{j}}{\partial t^{i}}=-\frac{1}{n} \frac{1}{f^{\prime \prime}(k)}>0, \quad \text { and } \quad \frac{\partial r}{\partial t^{i}}=-\frac{1}{n}<0,(1)
$$

where the responses are evaluated at $k^{i}=k^{-i}$. ${ }^{6}$ Optimizing firm behavior leads to indirect utility $v^{i}\left(t^{i}, \boldsymbol{t}^{-i}, g^{i}\right) .{ }^{7}$ Invoking the envelope theorem and setting $k^{i}=k^{-i}$

\footnotetext{
4The superscript ' (") denotes a function's first (second) derivative.

${ }^{5}$ More precisely, the production function exhibits constant returns to scale with respect to both inputs: capital and the fixed factor.

${ }^{6}$ The superscript $-i$ denotes a state other than state $i$.

${ }^{7} \boldsymbol{t}^{-\boldsymbol{i}}$ stands for a vector comprising all tax rates except for state $i$ 's tax rate.
} 
gives

$$
\frac{\partial v^{i}(\cdot)}{\partial t^{i}}=-k^{i}, \quad \frac{\partial v^{i}(\cdot)}{\partial t^{-i}}=0, \quad \text { and } \quad \frac{\partial v^{i}(\cdot)}{\partial g^{i}}=b_{g}^{i}
$$

The public sector is modelled as a two-layer federal system. State governments tax capital on a source-basis at rates $\left\{t^{i}>0\right\}_{i=1, \ldots, n}$. Tax revenues, $\left\{t^{i} k^{i}\right\}_{i=1, \ldots, n}$, are recycled by providing a local public good, $\left\{g^{i}=t^{i} k^{i}+s^{i}>0\right\}_{i=1, \ldots, n}$. The federal government provides lump-sum grants which are financed by contributions made by member states of the union. $\left\{s^{i}\right\}_{i=1, \ldots, n}$ denotes the net-of contribution payment each state receives (or pays if negative). Both levels of government are assumed to be benevolent. State governments maximize utility of the representative household. The federal government chooses policy to maximize the Benthamite welfare function $\sum_{i=1}^{n} v^{i}(\cdot)$.

Since regions are identical, attention is confined to symmetric equilibria, subsequently. ${ }^{8}$

\section{Nash-Behavior}

This section characterizes public policy if no government can commit to its policy. ${ }^{9}$ The outcome will later on be contrasted with the outcome prevailing under decentralized commitment. The decision sequence of the game is the following (Figure 1): ${ }^{10}$

\footnotetext{
${ }^{8}$ The stark symmetry assumption is invoked to exclusively focus on the incentive effects of ex-post lump-sum transfers on tax setting. With e.g. regional asymmetries in endowments or preferences, which typically create demand for federal transfers, the incentive (substitution) effects would be accompanied by redistributive (income) effects. The latter would originate from positive or negative equilibrium transfer payments.

${ }^{9}$ In line with top-down approach, federal commitment might be considered as a more appropriate benchmark. Note, in the current setting, both scenarios yield the same equilibrium allocation. Since transfer payments are zero in a symmetric equilibrium, the federal government cannot strategically influence state tax setting via lump-sum transfers. Therefore, any federal commitment to transfers is neutral.

${ }^{10}$ For simplicity, we suppress the final stage of the game at which production takes place, public goods are provided and are consumed together with the private good.
} 


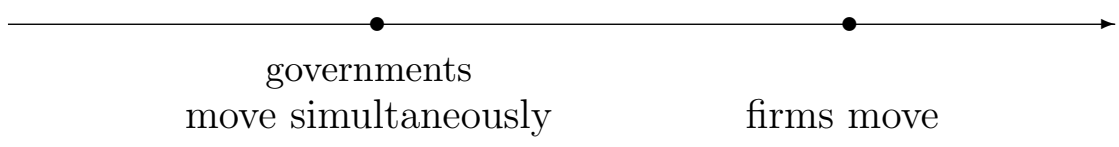

Figure 1: Sequence of moves: non-commitment.

First Stage: Both levels of government choose their policy instruments $\left\{t^{i}, s^{i}\right\}_{i=1, \ldots, n}$ simultaneously. They behave as Nash competitors, i.e. each government takes policy choices of other governments as given. However, they account for the effect on private agents' decisions.

Second Stage: At the second stage of the game, private agents decide on $\left\{k^{i}\right\}_{i=1, \ldots, n}$ for given policy instruments.

The game is solved by backward induction to identify a subgame-perfect equilibrium. Subsequently, attention is confined to symmetric equilibria, i.e. $k^{i}=\tilde{k}^{11}$

The behavior of private agents is sufficiently described by Eq. (2) which allows an immediate analysis of public sector behavior.

State Government State government $i$ sets its capital tax rate, $t^{i}$, for given $\left(s^{i}, \boldsymbol{t}^{-i}\right)$ to maximize the indirect utility of the representative household subject to the state's budget constraint

$$
\max _{t^{i}} \quad v^{i}\left(t^{i}, \boldsymbol{t}^{-i}, g^{i}\right) \quad \text { s.t. } \quad g^{i}=t^{i} k^{i}+s^{i} .
$$

Differentiating with respect to $t^{i}$, inserting Eq. (2), and rearranging yields

$$
b_{g}^{i}=\frac{1}{1+\epsilon^{i}} \quad \text { with } \quad \epsilon^{i}:=\frac{\partial k^{i}}{\partial t^{i}} \frac{t^{i}}{k^{i}} .
$$

\footnotetext{
${ }^{11}$ The stark assumption of symmetry is introduced to focus on the incentive effects of expost lump-sum transfers on tax setting. With e.g. regional asymmetries in endowments or preferences, which typically create demand for federal transfers, the incentive (substitution) effects are accompanied by redistributive (income) effects. The latter originate from actual positive or negative equilibrium transfer payments.
} 
Eq. (3) exhibits the well-known feature of capital tax competition: underprovision of local public goods. Given a perceived outflow of capital in response to a rise in capital taxation, captured by $\epsilon_{k^{i}, t^{i}}<0$, the state's marginal cost of public funds [r.h.s. of Eq. (3); henceforth SMCPF] exceeds the social marginal rate of transformation equal to unity. At an optimum the benefits of taxation, $b_{g}^{i}$, are equated to SMCPF, yielding $b_{g}^{i}>1$. Alternatively, tax competition can be viewed as imposing a horizontal fiscal externality on other states' tax revenues (Wildasin, 1989). The outflow of capital enlarges the tax base in neighboring states which constitutes a positive effect not accounted for by the tax-raising state. This failure implies inefficiently low tax rates.

Federal Government Given states' policy choices $\left\{t^{i}\right\}_{i=1, \ldots, n}$, the federal government solves

$$
\max _{\left\{s^{i}\right\}_{i=1, \ldots, n}} \sum_{i=1}^{n} v^{i}\left(t^{i}, \boldsymbol{t}^{-i}, g^{i}\right) \quad \text { s.t. } \quad g^{i}=t^{i} k^{i}+s^{i} \quad \text { and } \quad \sum_{i=1}^{n} s^{i}=0 .
$$

Using Eq. (2), the first-order conditions can be rewritten as

$$
b_{g}^{i}=b_{g}^{-i}
$$

The federal government sets transfers so as to equalize the marginal benefit of public consumption across states. Following concavity of $b(\cdot)$, any interstate difference in the marginal valuation of public consumption is equalized by transferring funds from the low-valuation to the high-valuation state. The first-order condition (4) and the federal budget constraint implicitly define the set of reaction functions $\left\{s^{i}=\varphi^{i}\left(t^{i}, \boldsymbol{t}^{-\boldsymbol{i}}\right)\right\}_{i=1, \ldots, n}$.

Since equilibrium transfers are zero, the subgame perfect equilibrium is equivalent to the Nash-equilibrium prevailing in a game between non-federated states moving simultaneously. The benchmark allocation thus coincides with the standard tax competition equilibrium - a result which subsequently allows for a meaningful welfare comparison. 


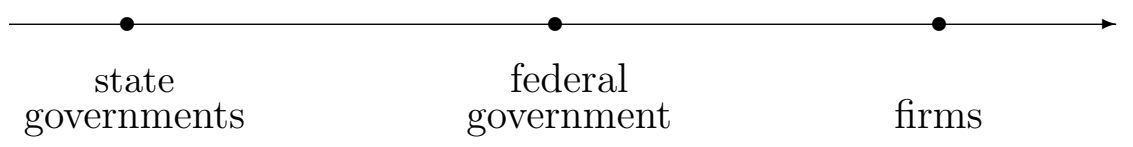

Figure 2: Sequence of moves: decentralized commitment.

\section{Decentralized Commitment}

In this section, states are assumed to act as Stackelberg leaders. Therefore, the sequence of decisions becomes (Figure 2): ${ }^{12}$

First Stage: States simultaneously select their capital tax rates $\left\{t^{i}\right\}_{i=1, \ldots, n}$ taking the reaction of the federal government and private agents into account. That is, state governments behave as Nash-competitors towards each other.

Second Stage: The federal level determines its policy variables $\left\{s^{i}\right\}_{i=1, \ldots, n}$ for given states' policy choices. It anticipates the reaction of private agents.

Third Stage: Private agents choose $\left\{k^{i}\right\}_{i=1, \ldots, n}$ for given policy at the federal and state level.

To characterize the subgame-perfect equilibrium, the game is solved by backwards induction. Given that private agents' decisions are sufficiently represented by Eq. (2), we can immediately turn to the second stage of the game.

Federal Government In any subgame-perfect equilibrium, transfer policy follows from the federal best-response functions $\left\{s^{i}=\varphi^{i}\left(t^{i}, \boldsymbol{t}^{-\boldsymbol{i}}\right)\right\}_{i=1, \ldots, n}$. To derive the federal best-reply to a change in state $i$ 's policy, the first-order condition (4) and the federal budget constraint, $\sum_{i=1}^{n} s^{i}=0$, is differentiated. For the partic-

\footnotetext{
${ }^{12}$ Again, the final stage of the game is suppressed; see footnote 10.
} 
ular case of equal tax rates, which will become relevant later, this yields

$$
\frac{\partial s^{i}}{\partial t^{i}}=\frac{1}{n} \sum_{j=1, j \neq i}^{n} \frac{\partial g^{j}}{\partial t^{i}}-\frac{n-1}{n} \frac{\partial g^{i}}{\partial t^{i}} .
$$

The best-reply of federal transfers $s^{i}$ separates into two effects. Firstly, the transfer scheme spreads the cross-budget effects of state $i$ 's tax policy evenly across all states, as captured by the first term in Eq. (5). Secondly, the transfer scheme "taxes" state $i$ 's marginal tax revenues, $\frac{\partial}{\partial t^{i}} g^{i}=\frac{\partial}{\partial t^{i}} t^{i} k^{i}$, at a rate $\frac{n-1}{n}$, where the "proceeds" are shared equally among the remaining $n-1$ states. Both effects ensure ex-post equalization of public funds as called for by the federal first-order condition (4).

State Government State government $i$ solves

$$
\begin{gathered}
\max _{t^{i}} \quad v^{i}\left(t^{i}, \boldsymbol{t}^{-\boldsymbol{i}}, g^{i}\right) \\
\text { s.t. } \quad g^{i}=t^{i} k^{i}+s^{i} \text { and } s^{i}=\varphi^{i}\left(t^{i}, \boldsymbol{t}^{-\boldsymbol{i}}\right) .
\end{gathered}
$$

After differentiation, inserting Eqs. (1) and (2) and imposing symmetry, the firstorder condition reads

$$
b_{g}^{i}=n .
$$

Given $n>1$, local public goods are underprovided in a subgame-perfect equilibrium. To rationalize why marginal benefits are equated to the size of the fiscal union, it is instructive to analyze the effect of a rise in $t^{i}$ on public funds available to state $i$. Differentiating $g^{i}$ and inserting Eq. (5) yields

$$
\begin{aligned}
\frac{d g^{i}}{d t^{i}} & =\frac{\partial g^{i}}{\partial t^{i}}+\frac{\partial s^{i}}{\partial t^{i}} \\
& =\frac{1}{n}\left(\frac{\partial g^{i}}{\partial t^{i}}+\sum_{j=1, j \neq i}^{n} \frac{\partial g^{j}}{\partial t^{i}}\right) \\
& =\frac{1}{n} k^{i},
\end{aligned}
$$

where the last equality is derived by using Eq. (1) and evaluating the expression at a symmetric equilibrium. 
The total effect decomposes in an own tax revenue effect, $\frac{\partial}{\partial t^{i}} g^{i}=\frac{\partial}{\partial t^{i}}{ }^{i} k^{i}$, and a transfer effect, $\frac{\partial}{\partial t^{i}} s^{i}$. Ignoring the term $\frac{1}{n}$ for the moment, ex-post federal intervention induces the social effects, following a marginal rise in $t^{i}$, to be pooled in state $i$ 's budget as captured by the bracketed term in Eq. (7). Federal transfers thus internalize horizontal fiscal externalities which eliminates tax competition. Consequently, from the perspective of each state government, the source-based capital tax, becomes a lump-sum tax which, taken in isolation, improves the efficiency of public policy.

However, with symmetric states the federal transfer scheme allocates only a fraction $\frac{1}{n}$ of $k^{i}$ to state $i$ 's budget so as to equalize public funds across states. Ex-post transfers therefore prove to be equivalent to an interstate revenue-sharing system which dilutes incentives to tax capital. Raising one unit of tax revenues requires private consumption to be reduced by $n$ units due to revenue sharing. The state marginal cost of public funds becomes equal to $n>1$, as shown in optimality condition (6), indicating underprovision of public goods in equilibrium. Proposition 1 summarizes the findings.

Proposition 1: Decentralized commitment internalizes horizontal fiscal externalities. However, interstate lump-sum redistribution effectively becomes an interstate revenue-sharing system rendering public good provision inefficient.

\section{Comparing Welfare}

Given symmetric states, welfare differences can be inferred from the tax rate differential $t^{d c}-t^{n c}$ where $t^{d c}$ and $t^{n c}$ denote equilibrium tax rates under decentralized and non-commitment, respectively. Lemma 1 and 2 compare tax rates chosen by union-member states which are small and large, respectively relative to the rest of the fiscal union. 


\section{Lemma 1: (Small member states) If $n \rightarrow \infty, t^{n c}>t^{d c}$.}

The dominance of the revenue sharing effect can best be rationalized by comparing the marginal cost of taxation under both regimes. Under decentralized commitment, the marginal cost of public funds, $n$, converges to infinity. The revenue sharing system allocates only a negligible fraction of the social marginal effect of a tax rise to the respective state budget. With tax competition, a rising $n$ magnifies the perceived response of the tax base to a rise in the tax rate, thereby increasing the marginal cost of taxation as well. However, the effect proves to be less pronounced. In fact, following Eqs. (1) and (3) SMCPF becomes $\left(1+t^{n c} / f^{\prime \prime}(1)\right)^{-1}<\infty$ which leaves states with stronger taxing incentives in tax competition relative to ex-post federal intervention.

For notational simplicity, $\gamma:=-f^{\prime \prime}(1)^{-1}$, subsequently. $\gamma$ has a ready economic interpretation. Since concavity of the production function is inversely related to the tax base elasticity, $\gamma$ provides a measure for the intensity of tax competition based on production technology. ${ }^{13}$

Lemma 2: (Large member states) Let the size of the fiscal union be $n \in[2, \infty)$. Then for every $n$, there exists a $\gamma^{*} \in[0, \tilde{\gamma})$ which yields $t^{d c}=t^{n c}$. Moreover,

$$
t^{d c} \gtreqless t^{n c} \Longleftrightarrow \gamma \gtreqless \gamma^{*} \quad \gamma \in[0, \tilde{\gamma})
$$

with $\tilde{\gamma}$ implicitly defined by $\epsilon^{i}\left(t^{d c}(n), n, \tilde{\gamma}\right)=-1$.

Contrary to $t^{d c}$, the tax rate under non-commitment $t^{n c}$ is influenced by $n$ as well as by $\gamma$. Fixing $n$, if tax competition becomes fierce enough as specified by

\footnotetext{
${ }^{13}$ Note, a higher degree of concavity requires less capital outflow in response to a tax rise to restore the arbitrage condition $f^{\prime}\left(k^{i}\right)-t^{i}=f^{\prime}\left(k^{-i}\right)-t^{-i}$. A second measure for tax competition fierceness is member state size. Rewriting Eq. (1) gives $\frac{\partial}{\partial t^{i}} k^{i}=-\gamma\left(1+\frac{\partial}{\partial t^{i}} r(n)\right)$. Larger values of $n$ diminish tax burden shifting onto capital owners by reducing interest rates which expose states to more competition. Both measures prove critical in the welfare comparison.
} 
$\gamma>\gamma^{*}(n), t^{n c}$ is sufficiently downward-pressured such that decentralized commitment yields higher welfare despite the presence of the revenue-sharing effect.

The example $b(g)=\ln g$ is used to illustrate $\gamma^{*}$ as a function of $n$. In this case, the threshold level, $\gamma^{*}$, takes the particularly simple form $\gamma^{*}=n$ for $n \geq 2 .{ }^{14}$ Figure 3 depicts parameter combinations for which $t^{d c}-t^{n c}$ becomes positive or negative. A noteworthy observation is that contrary to tax competition considerations a positive relation between the magnitude of $t^{d c}-t^{n c}$ and $\left|\epsilon^{i}\right|$ does not hold per se. Comparative statics in $\gamma$ indeed confirm this intuition. However, fixing $\gamma$, an increase in the size of the fiscal union $n$ tends to render $t^{d c}-t^{n c}$ negative though $\left|\epsilon^{i}\right|$ magnifies.

In order to plausibly assess the scope for tax competition (non-commitment) to yield higher welfare, we employ empirical estimates of demand elasticities as reported in Chirinko et al. (1999). A firm-level demand elasticity of -0.25 , which provides an upper bound (in absolute value) for the tax base elasticity $\epsilon^{i}{ }^{15}$ gives $1<\frac{1}{1+\epsilon^{i}}<2$. Following Eqs. (3) and (6), the marginal cost of public funds under tax competition appears to be less attenuated for $n \geq 2$, indicating $t^{d c}-t^{n c}<0$.

The results of Lemma 1 and 2 are summarized in Proposition 2.

Proposition 2: If member states are small, the effect of revenue-sharing under decentralized commitment unambiguously implies lower welfare relative to tax competition. With large member states, however, a ex-post transfer setting may prove to be welfare-superior.

\footnotetext{
${ }^{14}$ With this specification, tax rates amount to $t^{d c}=\frac{1}{n}$ and $t^{n c}=\frac{n}{n+\gamma(n-1)}$. Setting $t^{d c}=t^{n c}$ the threshold level $\gamma^{*}$ becomes equal to $n$ for $n>1$. In the limiting case, $n \rightarrow \infty t^{d c} \rightarrow 0$ and, given l'Hôpital's rule, $t^{n c} \rightarrow \frac{1}{1+\gamma}>0$ for $\gamma<\infty$. Therefore, $t^{n c}>t^{d c}$ as predicted by Lemma 1.

${ }^{15}$ To see this, note that the firm-level capital demand response to a higher tax rate reads $\frac{1}{f^{\prime \prime}\left(k^{i}\right)}$. The regional capital demand response (Eq.(1)) differs from the firm-level one by the term $\frac{n-1}{n}$ which falls below unity for any $n \geq 2$.
} 


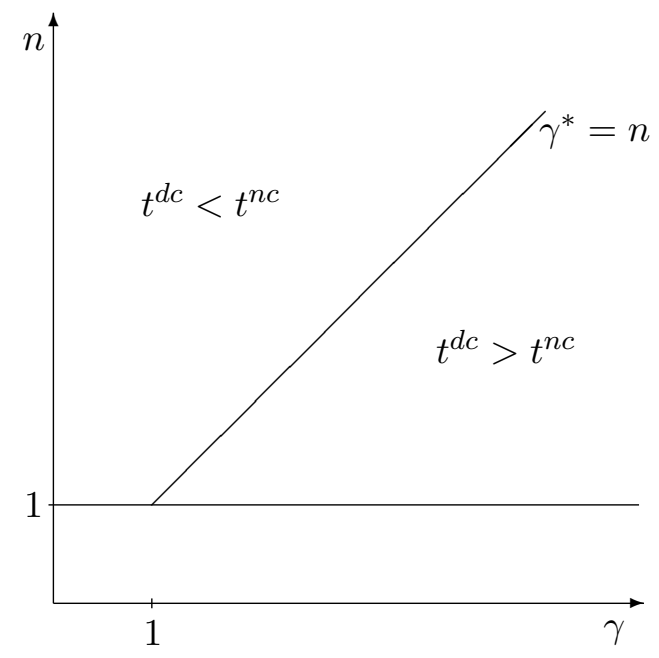

Figure 3: Welfare comparison for $b(g)=\ln g$.

The following lemma provides some more intuition for Proposition 2.

Lemma 3: With a fiscal union comprising $n$ symmetric states, it follows

$$
\left.t^{d c} \gtreqless t^{n c} \Longleftrightarrow \quad \frac{\partial s^{i}}{\partial t^{i}}\right|_{t^{i}=t^{n c}} \gtreqless 0 .
$$

The result has a straightforward explanation. Incentives to tax capital are strengthened if a higher capital tax rate translates into more transfers. As shown in Smart (1998), transfer competition (i.e. $\frac{\partial}{\partial t^{i}} s^{i}>0$ ) reduces welfare when not being complemented by tax competition. Governments are inclined to choose an inefficiently high tax rate in an attempt to attract transfers. Here, however, allowing for transfer competition proves beneficial since the prospects of higher transfers raises tax rates from an inefficiently low level. ${ }^{16}$

Additionally, Lemma 3 relates the paper to the literature on vertical fiscal externalities. Differentiating the sum of indirect utility except that of state $i$

\footnotetext{
${ }^{16}$ See Qian and Roland (1998) and Köthenbürger (2002) for a similar beneficial role of transfer competition.
} 
with respect to $t^{i}$ yields

$$
\sum_{j=1, j \neq i}^{n} \frac{d v^{j}}{d t^{i}}=\sum_{j=1, j \neq i}^{n} \frac{\partial v^{j}}{\partial g^{j}}(\underbrace{t^{j} \frac{\partial k^{j}}{\partial t^{i}}}_{(a)}+\underbrace{\frac{\partial s^{j}}{\partial t^{i}}}_{(b)}) .
$$

Term (a) captures the positive horizontal fiscal externality a marginal tax increase imposes on other state budgets. It is this effect which renders tax competition inefficient. Ex-post federal intervention allows for a second type of fiscal externality represented by the term $(b)$. A change in state $i$ 's tax policy alters public transfers allocated to other states which constitutes a vertical fiscal externality. Implied by symmetry and the federal budget constraint, horizontal fiscal externalities are mitigated by a negative vertical fiscal externality if $\left.\frac{\partial}{\partial t^{i}} s^{i}\right|_{t^{i}=t^{n c}}>0$ inducing states to select $t^{d c}>t^{n c}{ }^{17}$

The nature of the vertical fiscal externality differs from those analyzed in previous literature. ${ }^{18}$ Therein either federal tax setting exerts an externality on lower-level governments' budgets ("top-down" vertical fiscal externality) or vice versa ("bottom-up" vertical fiscal externality). With decentralized commitment, state tax policy affects other state budgets via federal policy changes. Continuing the analogy, this effect constitutes a "bottom-up-top-down" vertical fiscal externality.

\section{$6 \quad$ Extensions}

So far, the analysis has been confined to the basic Zodrow-Mieszkowski tax competition model extended by a federal level which allowed for a clear presentation of the results. Subsequently, the baseline model is extended in various ways to explore the robustness of the internalization and revenue-sharing effect of fiscal transfers.

\footnotetext{
${ }^{17}$ By Eq. (6), the horizontal fiscal externality always dominates the possibly counteracting vertical fiscal externality, precluding the possibility of overtaxation of capital as found in Keen and Kotsogiannis (2002).

${ }^{18}$ See Keen (1998) for a comprehensive overview of the literature on vertical fiscal externality.
} 


\subsection{Non-Union Member States}

Let $m>n$ denote the total number of symmetric states in the economy, $n$ of which form a fiscal union. If capital is allocated equally across all states, capital supply responses to a change in $t^{i}$ are identical to Eq. (1) except that $n$ has to be replaced by $m$. In the benchmark case of non-commitment, tax rates are still downward-distorted by capital mobility as shown in Eq. (3).

To analyze the allocative effects of decentralized commitment, consider a rise in the tax rate of state $i$, which is a member of the fiscal union. The transfer response continues to be captured by Eq. (5). In a symmetric equilibrium, the change in public funds available to state $i$ reads ${ }^{19}$

$$
\begin{aligned}
\frac{d g^{i}}{d t^{i}} & =\frac{1}{n}\left(k^{i}+t^{i}\left((n-1) \frac{\partial k^{-i}}{\partial t^{i}}+\frac{\partial k^{i}}{\partial t^{i}}\right)\right) \\
& =\frac{1}{n}\left(k^{i}+t^{i}\left(-(m-n) \frac{\partial k^{-i *}}{\partial t^{i}}\right)\right),
\end{aligned}
$$

where the last equation follows from the capital market clearing condition. Expost federal intervention internalizes horizontal fiscal externalities operating among member states of the fiscal union. Each member state perceives an outflow of capital only to the $m-n$ non-member states (Eq. (9)). Equilibrium tax rates follow from

$$
b_{g}^{i}=\frac{n}{1+\bar{\epsilon}^{i}} \quad \text { with } \quad \bar{\epsilon}^{i}:=\frac{\partial \bar{k}^{i}}{\partial t^{i}} \frac{t^{i}}{k^{i}} .
$$

Contrary to the baseline model in Section 4, tax policy is not completely insulated from capital mobility. Using Eq. (1), $\frac{\partial}{\partial t^{i}} \bar{k}^{i}=\frac{m-n}{m} \frac{1}{f^{\prime \prime}\left(k^{i}\right)}<0$. The response is lower than in the benchmark case (for $n>1$ ) reflecting the absorption of intra-union capital mobility by ex-post transfers. Moreover, it equals the capital supply response as perceived by the upper level. Intuitively, each member state accesses the international capital market with the market power of the whole fiscal union. The reduced overestimation of the marginal cost of public funds points to higher

\footnotetext{
${ }^{19}$ The superscript $-i(-i *)$ denotes a state other than state $i$ being (not being) a member of the fiscal union state $i$ belongs to.
} 
equilibrium tax rates relative to the benchmark. However, the partial effect is counteracted by ex-post federal equalization of tax revenues as captured by $n$ in Eq. (10).

\subsection{Distortionary Labor Taxation}

Let the second factor of production be labor, being endogenously supplied by each household and decreasing in the labor tax rate, $\tau$, levied by the state government. In the benchmark case the labor tax rate turns out to be downward-distorted by capital mobility (see Bucovetsky and Wilson (1991) for a detailed analysis). A rise in $\tau$ reduces labor supply which - given complementarity between labor and capital in production - lowers the net-of-tax rate of return on capital below the level prevailing in other states. The perceived outflow of capital in addition to the induced labor-leisure distortion implies labor taxes to be set at a third-best level .

Ex-post federal redistribution has the virtue of insulating labor tax policy from intra-union capital mobility which, other things being equal, pressures labor tax rates upwards to the second-best level. Perceiving that only a fraction $\frac{1}{n}$ of additional labor tax revenues accrues to the state's own budget, the labor tax rate will eventually be set below the second-best level.

\subsection{Household Mobility}

As documented in recent literature household mobility tends to improve efficiency of decentralized public finance (Myers, 1990). ${ }^{20}$ By responding to interregional utility differentials, mobile households create a welfare linkage between regions which at least partly internalize interregional externalities.

In the limit of perfect household mobility migration responses render symmetric capital tax competition efficient (Wellisch, 2000, p. 111). Since any utility differential between regions is arbitraged away, each regional government implicitly

\footnotetext{
${ }^{20}$ See Wellisch (2000) for a comprehensive survey of the literature.
} 
maximizes utility of all regions in the federation which aligns regional incentives to social incentives. Perfect incentive equivalence however fails to hold in the more realistic case of imperfect household mobility. In this case decentralized commitment complements imperfect household mobility in absorbing the effect of resource mobility on the efficiency of the public sector. Equal to the baseline model, levelling out interregional public consumption differences by ex-post transfer setting eliminates fiscal externalities in a symmetric equilibrium. Again, the resource allocation between the private and public sector becomes inefficient, however for reasons different to tax competition.

\section{Conclusion}

The paper shows that decentralized commitment fundamentally changes the nature of capital tax competition in a fiscal union. With capital tax rates set prior to federal transfers, horizontal fiscal externalities among members of the fiscal union are internalized. Ex-post federal intervention thus has the merit of neutralizing the impact of capital mobility on local tax policy. However, ex-post federal transfer policy effectively becomes an interstate revenue-sharing mechanism which implies that equilibrium tax rates are set at an inefficiently low level. Welfare analysis reveals that tax competition may appear to be the preferred federal governance structure.

The literature does not provide econometric guidance on which type of vertical commitment (i.e. (de)centralized commitment or even non-commitment) is more descriptive in federal economies. The only paper addressing the issue of commitment so far is Hayashi and Boadway (2001). Analyzing business tax setting in Canada, they find inconclusive results as to whether the federal government acts as a Stackelberg leader or Nash-competitor towards provinces. Given the lack of empirical evidence, it is however at least instructive to contrast the different

scenarios; especially if the policy outcomes fundamentally deviate as shown in 
the paper.

In particular, three diverging implications are noteworthy. Firstly, the more pronounced capital mobility among union member states ${ }^{21}$, originating e.g. from the creation of a single capital market in a union, does not necessarily imply fiercer tax competition as typically conjectured in the literature (e.g. Begg et al., 1993). Indeed, with ex-post transfers the potential advantage of a higher capital mobility can be reaped without suffering the costs associated with a more severe underprovision of public services. ${ }^{22}$

Secondly, even if potentially welfare-enhancing, tax coordination among independent states appears to be difficult to achieve in practice. Not only the potential non-verifiability of effective tax rates, but also the lack of institution enforcing tax coordination agreements between independent states partly explain this failure. ${ }^{23}$ The federal level may instead implicitly induce state governments to choose capital tax rates in a coordinated way by making contingent transfers (e.g. Wildasin, 1989, and Dahlby, 1996). The paper casts doubt on this frequently encountered argument. In fact, federal intervention, when coupled with commitment problems, may render unfettered tax competition welfare-superior. The paper thus underlines the need for a careful evaluation of second-best federal institutions for implementing tax coordination. ${ }^{24}$

Finally, tax and yardstick competition are argued to lie at the root of the empirically validated complementarity between local capital tax rates. ${ }^{25}$ Following the present paper, a third channel of interaction proves equally capable of explain-

\footnotetext{
${ }^{21}$ See e.g. Helliwell and McKitrick (1999) for an empirical analysis.

${ }^{22}$ A similar argument is derived in Persson and Tabellini (1992) by invoking political economy mechanisms. In particular, strategic delegation of politicians partly neutralizes the impact of economic integration on capital tax rates.

${ }^{23}$ Non-verifiability implies that any tax coordination agreement cannot be conditioned on effective tax rates. Only a subset of instruments, ultimately influencing effective tax rates, can be part of such an agreement (e.g. statutory tax rates). Facing this incompleteness, partial coordination may result in even fiercer tax competition via tax instruments still under local discretion; see Crémer and Gahvari (2000).

${ }^{24}$ See Kehoe (1989), Janeba (2000), and Perroni and Scharf (2001) for a related cautious argument on the desirability of federally-mediated policy coordination.

${ }^{25}$ See Brueckner (2001) for a survey.
} 
ing the interaction. More precisely, equilibrium tax interaction may exclusively be generated by federal transfers even in the presence of capital mobility. Disentangling the various sources of strategic interaction may therefore be a fruitful avenue for future empirical research, shedding more light on the relevance of the tax competition argument relative to competing explanations.

\section{A Appendix}

\section{A.1 Proof of Lemma 1}

Comparing Eqs. (3) and (6) reveals that $t^{d c}-t^{n c} \gtreqless 0$ iff $-\left.\frac{n-1}{n} \gtreqless \epsilon^{i}\right|_{t^{i}=t^{n c}}$. For $n \rightarrow \infty$, the term $-\frac{n-1}{n}$ approaches -1 giving $t^{d c}-t^{n c} \gtreqless 0$ iff $-\left.1 \gtreqless \epsilon^{i}\right|_{t^{i}=t^{n c}}$. The rest of the proof proceeds by first proving the existence of $t^{n c}$. In a second step, it is shown that at the non-commitment equilibrium, $-1<\left.\epsilon^{i}\right|_{t^{i}=t^{n c}}$.

First step: Inserting Eq. (1) into the right-hand-side of Eq. (3) and evaluating the term at $\tilde{k}=1$ shows that SMCPF is equal to $\left(1+t / f^{\prime \prime}(1)\right)^{-1}$ for $n \rightarrow \infty$. Note, if $t \uparrow-f^{\prime \prime}(1), \mathrm{SMCPF} \rightarrow \infty$ and if $t \rightarrow 0, \mathrm{SMCPF} \rightarrow 1$. Given monotonicity and continuity of SMCPF and condition (A) imposed on $b^{\prime}(g)$, there always exists a unique tax rate $t^{n c} \in\left(0,-f^{\prime \prime}(1)\right)$ satisfying Eq. (3).

Second step: Following Eq. (1) and $\tilde{k}=1,\left.\epsilon^{i}\right|_{t^{i}=t^{n c}}=t^{n c} f^{\prime \prime}(1)^{-1}$ for $n \rightarrow \infty$. As shown in the first step, $t^{n c}<-f^{\prime \prime}(1)$ yielding $\left.\epsilon^{i}\right|_{t^{i}=t^{n c}}>-1$, which completes the proof.

\section{A.2 Proof of Lemma 2}

Let the size of the fiscal union be given by $n \in(1, \infty)$. Eq. (6) uniquely defines $t^{d c}$ as a function of $n$. Now, insert $t^{d c}(n)$ in $\epsilon^{i}$ evaluated at a symmetric equilibrium. Using (1), $\epsilon^{i}$ can now be written as a function of $n$ and $\gamma$, i.e. $\tilde{\epsilon}(n, \gamma):=\epsilon^{i}\left(t^{d c}(n), n, \gamma\right)$. Note, if $\gamma \rightarrow 0, \tilde{\epsilon}(n, \gamma)$ goes to 0 . Furthermore, if $\gamma \rightarrow \infty, \tilde{\epsilon}(n, \gamma)$ converges to $-\infty$ and - given continuity of $\tilde{\epsilon}(n, \gamma)$ - the intermediate value theorem guarantees a value of $\tilde{\gamma}$ which yields $\tilde{\epsilon}(n, \tilde{\gamma})=-1$. At an interior solution, we thus have $\gamma \in[0, \tilde{\gamma})$. Again, given by the intermediate value theorem, there exists a value $\gamma^{*} \in[0, \tilde{\gamma})$ which satisfies $\tilde{\epsilon}\left(n, \gamma^{*}\right)=-\frac{n-1}{n}$. Following Eqs. (3) and (6), $t^{d c}-t^{n c} \gtreqless 0$ iff $-\left.\frac{n-1}{n} \gtreqless \epsilon^{i}\right|_{t^{i}=t^{n c}}$. Therefore, $t^{d c}$ and 
$t^{n c}$ coincide for parameter values $n$ and $\gamma^{*}$, proving the first assertion in Lemma 2 .

To prove the second assertion, note that following Eqs. (3) and (6)

$$
\frac{d t^{d c}}{d \gamma}=0 \quad \text { and } \quad \frac{d t^{n c}}{d \gamma}<0 .
$$

Starting from $n$ and $\gamma^{*}$, the tax differential $t^{d c}-t^{n c}$ increases as $\gamma$ increases which gives condition (8).

\section{A.3 Proof of Lemma 3}

Given Eqs. (3) and (6), $t^{d c}-t^{n c} \gtreqless 0$ iff $-\left.\frac{n-1}{n} \gtreqless \epsilon^{i}\right|_{t^{i}=t^{n c}}$. Evaluating Eq. (5) in a symmetric equilibrium, inserting Eq. (1), and using the aforementioned condition, proves Lemma 3.

\section{References}

[1] Begg, D., J. Crémer, J.P. Danthine, J. Edwards, V. Grilli, D. Neven, P. Seabright, H.W. Sinn, A. Venables, and Ch. Wyplosz (1993): Making Sense of Subsidiarity: How Much Centralization for Europe?, Monitoring European Integration 4, A CEPR Annual Report, London.

[2] Bjorvatn, K. and G. Schjelderup (2002): Tax Competition and International Public Goods, International Tax and Public Finance, 9, 111 - 120.

[3] Boadway, R. and F.R. Flatters (1982): Efficiency and Equalization Payments in a Federal System of Government, A Synthesis and Extension of Recent Results, Canadian Journal of Economics, 15, 613 - 633.

[4] Boadway, R., and M. Keen (1996): Efficiency and the Optimal Direction of Federal-State Transfers, International Tax and Public Finance, 3, 137 - 155.

[5] Boadway, R., M. Marchand, and M. Vigneault (1998): The Consequences of Overlapping Tax Bases for Redistribution and Public Spending in a Federation, Journal of Public Economics, 68, 453 - 478. 
[6] Bucovetsky, S. and J.D. Wilson (1991): Tax Competition with Two Tax Instruments, Regional Science and Urban Economics, 21, 333 - 350.

[7] Brueckner, J.K. (2001): Strategic Interaction Among Governments: An Overview of Empirical Studies, mimeo, University of Illinois at UrbanaChampaign.

[8] Caplan, A.J., R.C. Cornes, and E.C.D. Silva (2000): Pure Public Goods and Income Redistribution in a Federation with Decentralized Leadership and Imperfect Labor Mobility, Journal of Public Economics, 77, 265 - 284.

[9] Chirinko, R.S., St.M. Fazzari, and A.P. Meyer (1999): How Responsive is Business Capital Formation to Its User Cost? An Exploration with Micro Data, Journal of Public Economics, 74, 53 - 80.

[10] Crémer, H. and F. Gahvari (2000): Tax Evasion, Fiscal Competition and Economic Integration, European Economic Review, 44, 1633-1657.

[11] Dahlby, B. (1996): Fiscal Externalities and the Design of Intergovernmental Grants, International Tax and Public Finance, 3, 397 - 412.

[12] Hayashi, M. and R. Boadway (2001): An Empirical Analysis of Intergovernmental Tax Interaction: The Case of Business Income Taxes in Canada, Canadian Journal of Economics, 34, 481-503.

[13] Helliwell, J.F. and R. McKitrick (1999): Comparing Capital Mobility across Provincial and National Borders, Canadian Journal of Economics, 23, 11641173.

[14] Janeba, E. (2000): Tax Competition when Governments Lack Commitment: Excess Capacity as a Countervailing Threat, American Economic Review, 90, 1508-1519.

[15] Keen, M. (1998): Vertical Tax Externalities in the Theory of Fiscal Federalism, IMF Staff Papers, 45, 454 - 485.

[16] Keen, M. and Ch. Kotsogiannis (2002): Does Federalism Lead to Excessively High Taxes?, American Economic Review, 92, 363 - 370. 
[17] Kehoe, P. (1989): Policy Cooperation Among Benevolent Governments May Be Undesirable, Review of Economic Studies, 56, 289 - 296.

[18] Köthenbürger, M. (2002): Tax Competition and Fiscal Equalization, International Tax and Public Finance, 9, 391 - 408.

[19] Messere, K. (ed.) (1998): The Tax System in Industrialized Countries, Oxford University Press, Oxford.

[20] Mitsui, K. and M. Sato (2001): Ex Ante Free Mobility, Ex Post Immobility, and Time Consistency in a Federal System, Journal of Public Economics, $82,445-460$.

[21] Myers, G.M. (1990): Optimality, Free Mobility, and the Regional Authority in a Federation, Journal of Public Economics, 43, 107 - 121.

[22] Oates, W.E. (1994): Federalism and Government Finance, in: Quigley, J.M. and E. Smolensky (eds.): Modern Public Finance, Harvard University Press, Cambridge.

[23] Perroni, C. and K. Scharf (2001): Tiebout with Politics: Capital Tax Competition and Constitutional Choices, Review of Economic Studies, 68, 133 154.

[24] Persson, T. and G. Tabellini (1992): The Politics of 1992: Fiscal Policy and European Integration, Review of Economic Studies, 59, 689 - 701.

[25] Poterba, J.M. (1995): Capital Budgets, Borrowing Rules, and State Capital Spending, Journal of Public Economics, 56, 165 - 187.

[26] Qian, Y. and G. Roland (1998): Federalism and the Soft Budget Constraint, American Economic Review, 88, 1143 - 1162.

[27] Rodden, J.A. (2003): Soft Budget Constraints and German Federalism, in: J.A. Rodden, G. Eskeland, and J. Litvack (eds.): Fiscal Decentralization and the Challenge of Hard Budget Constraints, MIT Press, Cambridge.

[28] Rodden, J.A., G. Eskeland, and J. Litvack (eds.) (2003): Fiscal Decentralization and the Challenge of Hard Budget Constraints, MIT Press, Cambridge. 
[29] Silva, E.C.D., and A.J. Caplan (1997): Transboundary Pollution Control in Federal Systems, Journal of Environmental Economics and Management, 34, $173-186$.

[30] Smart, M. (1998): Taxation and Deadweight Loss in a System of Intergovernmental Transfers, Canadian Journal of Economics, 31, 189-206.

[31] Wellisch, D. (2000): Theory of Public Finance in a Federal State, Cambridge University Press, Cambridge.

[32] Wildasin, D.E. (1989): Interjurisdictional Capital Mobility: Fiscal Externality and a Corrective Subsidy, Journal of Urban Economics, 25, 193 - 212.

[33] Wildasin, D.E. (1997): Externalities and Bailouts. Hard and Soft Budget Constraints in Intergovernmental Fiscal Relations, Working Paper No. 1843, World Bank, Washington.

[34] Zodrow, G.R. and P. Mieszkowski (1986): Pigou, Tiebout, Property Taxation, and the Underprovision of Local Public Goods, Journal of Urban Economics, 19, 356 - 370. 


\section{CESifo Working Paper Series}

(for full list see www.cesifo.de)

877 Robin Boadway and Jean-François Tremblay, Public Economics and Startup Entrepreneurs, February 2003

878 Erkki Koskela and Roope Uusitalo, The Un-Intended Convergence: How the Finnish Unemployment Reached the European Level, February 2003

879 Robert Fenge and Volker Meier, Pensions and Fertility Incentives, February 2003

880 Eytan Sheshinski, Note on Income Taxation and Occupational Choice, February 2003

881 A B Atkinson, Income Inequality in OECD Countries: Data and Explanations, February 2003

882 Thomas Gehrig and Rune Stenbacka, Venture Cycles: Theory and Evidence, February 2003

883 Ralf Becker and Thomas Hellmann, The Genesis of Venture Capital - Lessons from the German Experience, March 2003

884 Eytan Sheshinski, Note on the Optimum Pricing of Annuities, March 2003

885 Paul De Grauwe and Magdalena Polan, Globalisation and Social Spending, March 2003

886 F. van der Ploeg, Do Social Policies Harm Employment and Growth?, March 2003

887 Mirjam van Praag, Initial Capital Constraints Hinder Entrepreneurial Venture Performance: An empirical analysis, March 2003

888 Bernard Steunenberg, Coordinating Sectoral Policymaking: Searching for Countervailing Mechanisms in the EU Legislative Process, March 2003

889 Eytan Sheshinski, Optimum Delayed Retirement Credit, March 2003

890 Frederick van der Ploeg, Rolling Back the Public Sector - Differential effects on employment, investment and growth, March 2003

891 Paul De Grauwe and Marc-Alexandre Sénégas, Monetary Policy in EMU when the Transmission is Asymmetric and Uncertain, March 2003

892 Steffen Huck and Kai A. Konrad, Strategic Trade Policy and the Home Bias in Firm Ownership Structure, March 2003

893 Harry Flam, Turkey and the EU: Politics and Economics of Accession, March 2003 
894 Mathias Hoffmann and Ronald MacDonald, A Re-examination of the Link between Real Exchange Rates and Real Interest Rate Differentials, March 2003

895 Badi H. Baltagi, Espen Bratberg, and Tor Helge Holmås, A Panel Data Study of Physicians' Labor Supply: The Case of Norway, March 2003

896 Dennis C. Mueller, Rights and Citizenship in the European Union, March 2003

897 Jeremy Edwards, Gains from Trade in Tax Revenue and the Efficiency Case for Trade Taxes, March 2003

898 Rainer Fehn and Thomas Fuchs, Capital Market Institutions and Venture Capital: Do They Affect Unemployment and Labour Demand?, March 2003

899 Ronald MacDonald and Cezary Wójcik, Catching Up: The Role of Demand, Supply and Regulated Price Effects on the Real Exchange Rates of Four Accession Countries, March 2003

900 R. Selten, M. Schreckenberg, T. Pitz, T. Chmura, and S. Kube, Experiments and Simulations on Day-to-Day Route Choice-Behaviour, April 2003

901 Stergios Skaperdas, Restraining the Genuine Homo Economicus: Why the Economy Cannot be Divorced from its Governance, April 2003

902 Yin-Wong Cheung, Menzie D. Chinn, and Antonio Garcia Pascual, What Do We Know about Recent Exchange Rate Models? In-Sample Fit and Out-of-Sample Performance Evaluated, April 2003

903 Mika Widgrén, Enlargements and the Principles of Designing EU - Decision-Making Procedures, April 2003

904 Phornchanok Cumperayot, Dusting off the Perception of Risk and Returns in FOREX Markets, April 2003

905 Kai A Konrad, Inverse Campaigning, April 2003

906 Lars P. Feld and Stefan Voigt, Economic Growth and Judicial Independence: Cross Country Evidence Using a New Set of Indicators, April 2003

907 Giuseppe Bertola and Pietro Garibaldi, The Structure and History of Italian Unemployment, April 2003

908 Robert A.J. Dur and Otto H. Swank, Producing and Manipulating Information, April 2003

909 Christian Gollier, Collective Risk-Taking Decisions with Heterogeneous Beliefs, April 2003

910 Alexander F Wagner, Mathias Dufour, and Friedrich Schneider, Satisfaction not Guaranteed - Institutions and Satisfaction with Democracy in Western Europe, April 2003 
911 Ngo Van Long, Raymond Riezman, and Antoine Soubeyran, Trade, Wage Gaps, and Specific Human Capital Accumulation, April 2003

912 Andrea Goldstein, Privatization in Italy 1993-2002: Goals, Institutions, Outcomes, and Outstanding Issues, April 2003

913 Rajshri Jayaraman and Mandar Oak, The Signaling Role of Municipal Currencies in Local Development, April 2003

914 Volker Grossmann, Managerial Job Assignment and Imperfect Competition in Asymmetric Equilibrium, April 2003

915 Christian Gollier and Richard Zeckhauser, Collective Investment Decision Making with Heterogeneous Time Preferences, April 2003

916 Thomas Moutos and William Scarth, Some Macroeconomic Consequences of Basic Income and Employment Subsidies, April 2003

917 Jan C. van Ours, Has the Dutch Miracle Come to an End?, April 2003

918 Bertil Holmlund, The Rise and Fall of Swedish Unemployment, April 2003

919 Bernd Huber and Marco Runkel, Optimal Design of Intergovernmental Grants under Asymmetric Information, April 2003

920 Klaus Wälde, Endogenous Business Cycles and Growth, April 2003

921 Ramon Castillo and Stergios Skaperdas, All in the Family or Public? Law and Appropriative Costs as Determinants of Ownership Structure, April 2003

922 Peter Fredriksson and Bertil Holmlund, Improving Incentives in Unemployment Insurance: A Review of Recent Research, April 2003

923 Bernard M.S. van Praag and Adam S. Booij, Risk Aversion and the Subjective Time Discount Rate: A Joint Approach, April 2003

924 Yin-Wong Cheung, Kon S. Lai, and Michael Bergman, Dissecting the PPP Puzzle: The Unconventional Roles of Nominal Exchange Rate and Price Adjustment, April 2003

925 Ugo Trivellato and Anna Giraldo, Assessing the 'Choosiness' of Job Seekers. An Exploratory Approach and Evidence for Italy, April 2003

926 Rudi Dornbusch and Stanley Fischer, International Financial Crises, April 2003

927 David-Jan Jansen and Jakob de Haan, Statements of ECB Officials and their Effect on the Level and Volatility of the Euro-Dollar Exchange Rate, April 2003

928 Mario Jametti and Thomas von Ungern-Sternberg, Assessing the Efficiency of an Insurance Provider - A Measurement Error Approach, April 2003 
929 Paolo M. Panteghini and Guttorm Schjelderup, Competing for Foreign Direct Investments: A Real Options Approach, April 2003

930 Ansgar Belke, Rainer Fehn, and Neil Foster, Does Venture Capital Investment Spur Employment Growth?, April 2003

931 Assar Lindbeck, Sten Nyberg, and Jörgen W. Weibull, Social Norms and Welfare State Dynamics, April 2003

932 Myrna Wooders and Ben Zissimos, Hotelling Tax Competition, April 2003

933 Torben M. Andersen, From Excess to Shortage - Recent Developments in the Danish Labour Market, April 2003

934 Paolo M. Panteghini and Carlo Scarpa, Irreversible Investments and Regulatory Risk, April 2003

935 Henrik Jacobsen Kleven and Claus Thustrup Kreiner, The Marginal Cost of Public Funds in OECD Countries. Hours of Work Versus Labor Force Participation, April 2003

936 Klaus Adam, George W. Evans, and Seppo Honkapohja, Are Stationary Hyperinflation Paths Learnable?, April 2003

937 Ulrich Hange, Education Policy and Mobility: Some Basic Results, May 2003

938 Sören Blomquist and Vidar Christiansen, Is there a Case for Public Provision of Private Goods if Preferences are Heterogeneous? An Example with Day Care, May 2003

939 Hendrik Jürges, Kerstin Schneider, and Felix Büchel, The Effect of Central Exit Examinations on Student Achievement: Quasi-experimental Evidence from TIMSS Germany, May 2003

940 Samuel Bentolila and Juan F. Jimeno, Spanish Unemployment: The End of the Wild Ride?, May 2003

941 Thorsten Bayindir-Upmann and Anke Gerber, The Kalai-Smorodinsky Solution in Labor-Market Negotiations, May 2003

942 Ronnie Schöb, Workfare and Trade Unions: Labor Market Repercussions of Welfare Reform, May 2003

943 Marko Köthenbürger, Tax Competition in a Fiscal Union with Decentralized Leadership, May 2003 